[17] Guisan, J. M. (Ed.) (2006). Immobilization of Enzymes and Cells. Methods in Biotechnology, 128. doi: 10.1007/978-1-59745-053-9

[18] Petrova, S., Parahin, N. (2013). Microbial preparations as a mean of forming effective plantmicrobial systems. Leguminous and groat cultures, 2 (6), 86-91.

[19] Sadykova, V. S., Kurakov, A. V. (2013). Prospects for the use of strains of the genus Trichoderma to obtain vermicomposts with fungicides and growth-stimulating properties. Russian Agricultural Sciences, 39 (3), 257-260. doi: 10.3103/s106836741303018x

[20] Romanenko, N., Popov, I., Tabolin, S., Bugaeva, E. N, Zaec, V. G. (2008). Perspectives of using antagonist bacteria against the most phytopathogenic species of nematodes, viruses and fungi. Agro XXI, $1-3,23-27$.

\title{
THE STUDY OF FATTY AND ORGANIC ACIDS COMPOSITION IN QUINCE LEAVES AND FRUITS (CYDONIA OBLONGA MILL)
}

\author{
Tetiana Dzhan \\ Department of Microbiology, Modern Biotechnology, \\ Ecology and Immunology \\ Open International University of Human Development "Ukraine" \\ 23 Lvivska str., Kyiv, Ukraine, 03179 \\ zakucilo@gmail.com
}

\begin{abstract}
The composition of fatty and organic acids in quince leaves and fruits (Cydonia oblonga Mill.) of selection of M. M. Grishko National Botanical Garden of National Academy of Sciences of Ukraine sorts was determined by gas chromatography-mass spectrometry method. Six sorts of quince were examined: "Academichna", "Kashchenka N18", "Studenrka', "Oranzheva", "Maria", "Darunok onuku". The presence of 36 fatty acids and 32 organic acids in leaves and fruits of the quince were identified and determined their content. Therefore, main acids are oxalic, citric, palmitic and linolenic acids in quince leaves and malic, palmitic and linoleic acids in quince fruits. The highest content of all acids were identified in the quince leaves of sort "Maria". Moreover, a quite high content of succinic acid in the quince leaves was detected.
\end{abstract}

Keywords: quince, fatty acids, organic acids, gas chromatography-mass spectrometry method.

\section{Introduction}

The quince (Cydonia oblonga Mill.) is recognized as a raw material for gelling products, due to the high content of pectin substances which are natural sorbents and they main function is removing body toxins and radio nuclides. The quince has known from ancient times, but unfortunately, is not always sufficiently evaluated. Now quince plays an important role in the economy of some countries and in other countries it is used only to meet domestic needs. Natural habitat of quince is Eastern and Southern Transcaucasia, Asia Minor, Iran. In other parts of the world the wild quince has not been discovered. The quince is cultivated in more than 40 countries, mainly in the humid continental and subtropical climates. But mainly in many countries its plantations are small and the quince may only be found in private gardens.

Study of the chemical composition and pharmacological activity of quince has shown positive prospects of quince fruits and leaves usage for drugs creation [1-15].

In Ukraine, quince is grown in small amounts; mainly in the south-western and southern regions with an average temperature from $10^{\circ} \mathrm{C}$ to $15^{\circ} \mathrm{C}$ and the length of growing season 
240-245 days. The part of quince among horticultural crops planting in Ukraine is $0.33 \%$. Productivity of quince in Ukraine is $1-2.5 \mathrm{~kg} / \mathrm{m}^{2}$ and depends on the climatic conditions, the sort and agronomic properties. Currently the quince is mainly grown in Ukrainian private households. In recent years, the cultivation of the quince is possible in the northern regions of Ukraine with an average temperature from $7{ }^{\circ} \mathrm{C}$ to $10{ }^{\circ} \mathrm{C}$. Assortment of quince in Northern Ukraine is represented by some local forms and sorts mainly breeding by M. M. Grishko National Botanical Garden (NBG). Those objects are highly perspective for cultivation in the northern regions of Ukraine. In addition, some sorts of quince tolerating for the temperature decrease to $-30-35{ }^{\circ} \mathrm{C}$ were bred. This achievement was possible due to the work of the NBG. In conclusion, the border of the quince cultivation was moved for about $500 \mathrm{~km}$ from its original cultivation area to north. Works with the quince are the realization of academician Kashchenko ideas about the possibility of quince cultivation in Northern Ukraine. Furthermore, the sorts "Darunok Onuku”, “Studentka”, "Maria”, "Kashchenka № 18”, “Mria Shaydarovoy” resisting to critically low temperatures were created. Five sorts of the quince were listed in the Register of Plant Sorts of Ukraine [16].

The study of quince biologically active substances [17-22] and quince pharmacological activity [23-26] of NBG sorts have been studied during the last five years. Those studies showed that quince leaves of the sort "Oranzheva" may be used as a hepatoprotector and the sort "Academichna" as an antiulcer drug.

\section{Aim}

Study of the fat and organic acids composition in quince leaves by gas chromatography-mass spectrometry method.

\section{Materials and methods}

Leaf samples were collected from 6 sorts of quince breeding by NBG: "Academichna", "Kashchenka N18", "Studenrka", "Oranzheva", "Maria", "Darunok onuku". Leaves were collected in June and fruits were collected in September of 2013. Raw materials were ground to 1-3 $\mathrm{mm}$ particles and used for receiving chloroform-forming fractions by gas chromatography-mass spectrometry method.

Experimental procedure

Methyl esters of fatty acids were obtained by a Peysker modified method. A mixture of chloroform with methanol and sulfuric acid in a ratio 100:100:1 was used for methylation. $30-50 \mathrm{ml}$ of lipophilic extract was placed in a glass vial and $2.5 \mathrm{ml}$ of a mixture was added for methylation, and ampoules were sealed. Ampoules were placed in a thermostat with a temperature of $105^{\circ} \mathrm{C}$ for 3 hours. Ampoules were opened after the end of the methylation, their contents were transferred to a test tube, and powdered zinc sulphate was added on the tip of a scalpel as well as $2 \mathrm{ml}$ water and $2 \mathrm{ml}$ of hexane for methyl esters extraction. After careful shaking, hexanoic extracts were filtered and used for chromatographic analysis.

Injection into the chromatographic column was carried out in splitless mode. The speed of a sample injection is $1.2 \mathrm{ml} / \mathrm{min}$ for 0.2 minutes. Chromatograph Agilent Technologies 6890 with a mass spectrometer detector 5973. Chromatography column - capillary DB-5 with interne diameter $0.25 \mathrm{~mm}$ and a length of $30 \mathrm{~m}$. Speed of carrier gas (helium) is $1.2 \mathrm{ml} / \mathrm{min}$. Temperature of sample introduction heater is $250{ }^{\circ} \mathrm{C}$. Temperature of thermostat is programmed from 50 to $320^{\circ} \mathrm{C}$ with a speed of $4{ }^{\circ} \mathrm{C} / \mathrm{min}$.

The mass spectra library NIST05 and WILEY 2007 with a total of more than 470.000 specters were used for components identification, as well as identification programs AMDIS and NIST. Internal standard method was used for quantitative calculations.

\section{Results}

In quince leaves were identified 36 fatty and organic acids, whereas 29 among them are common to all of the samples (Table 1). 
Table 1

Fatty and organic acids of quince leaves

\begin{tabular}{|c|c|c|c|c|c|c|}
\hline \multirow{2}{*}{ Name of the acid } & \multicolumn{6}{|c|}{ Content in leaves of sorts, $\mathrm{mg} / \mathrm{kg}$ dry plant } \\
\hline & Academichna & Kashchenko N18 & Studentka & Oranzheva & Maria & Darunok onuku \\
\hline Capronic & 52.2 & 42.3 & 52.7 & 68.2 & 79.2 & 54.2 \\
\hline 2-Hexenic & 53.1 & 29.1 & 58.9 & 92.5 & 53.2 & 37.8 \\
\hline 3-Hexenic & 145.3 & 109.5 & 182.7 & 232.0 & 213.2 & 126.4 \\
\hline Oxalic & 3049.8 & 2495.6 & 2696.5 & 2650.6 & 2757.6 & 2010.9 \\
\hline Malonic & 255.8 & 173.0 & 175.0 & 182.1 & 274.6 & 235.2 \\
\hline Succinic & 502.4 & 417.5 & 281.7 & 557.1 & 472.7 & 208.0 \\
\hline Glutaric & 10.9 & & & & 21.5 & 8.2 \\
\hline Adipic & 9.1 & 6.7 & 12.5 & 12.8 & 14.1 & 8.1 \\
\hline Azelaic & 71.1 & 67.6 & 71.0 & 105.6 & 95.0 & 20.8 \\
\hline Fumaric & 42.2 & 38.7 & 29.9 & 60.2 & 56.7 & 30.2 \\
\hline Benzoic & 184.5 & 198.1 & 212.7 & 583.3 & 267.7 & 174.3 \\
\hline Phenylacetic & 10.6 & 7.0 & 8.3 & 9.7 & 13.4 & 15.6 \\
\hline Salicylic & 29.6 & 26.8 & 22.8 & 29.5 & 23.5 & 21.6 \\
\hline Vanillic & 18.9 & 14.9 & 21.5 & 23.4 & 19.6 & 11.0 \\
\hline Malic & 444.7 & 523.5 & 260.4 & 418.9 & 41.2 & 5.9 \\
\hline 3-Oxy-2-methylglutaric & & & & 118.1 & 69.9 & \\
\hline Citric & 1274.7 & 924.5 & 687.1 & 1062.0 & 2255.1 & 724.2 \\
\hline Cinnamic & & & 101.5 & 96.5 & 109.2 & 10.3 \\
\hline$p$-Coumaric & 13.4 & 13.3 & 17.0 & & & \\
\hline Ferulic & & 6.2 & 5.8 & 9.6 & & \\
\hline Lauric & 37.3 & 28.9 & 34.0 & 32.4 & 35.3 & 34.0 \\
\hline Myristic & 88.2 & 110.2 & 96.6 & 53.3 & 90.6 & 70.8 \\
\hline Pentadecanoic & 18.5 & 15.9 & 20.8 & 28.9 & 33.1 & 65.2 \\
\hline Palmitic & 2330.9 & 2078.6 & 2620.7 & 2517.0 & 3484.6 & 2582.0 \\
\hline Palmitoleic & 177.5 & 178.7 & 221.9 & 172.0 & 338.0 & 253.5 \\
\hline Heptadecanoic & 19.6 & 16.8 & 22.3 & 23.9 & 26.8 & 27.3 \\
\hline Stearic & 137.8 & 139.2 & 148.8 & 152.0 & 291.3 & 150.9 \\
\hline Oleic & 120.9 & 144.9 & 121.4 & 123.2 & 231.9 & 123.9 \\
\hline Linoleic & 492.6 & 411.6 & 513.8 & 360.2 & 561.5 & 628.1 \\
\hline Linolenic & 1086.4 & 1021.3 & 1236.4 & 809.8 & 1688.3 & 1547.6 \\
\hline Arachinic & 48.9 & 46.3 & 48.1 & 49.1 & 86.4 & 65.4 \\
\hline Heneicosanoic & 9.2 & 7.1 & 8.6 & 8.4 & 12.7 & 14.3 \\
\hline Begenic & 32.3 & 38.8 & 33.2 & 34.4 & 56.2 & 49.0 \\
\hline Tricosanoic & & & & & 6.9 & 10.6 \\
\hline Tetracosanoic & 16.4 & 18.2 & 15.5 & 8.3 & 18.2 & 24.5 \\
\hline Hexacosanoic & 7.8 & 10.7 & 10.1 & 9.3 & & \\
\hline
\end{tabular}


In quince fruits were identified 32 fatty and organic acids, whereas 22 among them are common to all of the samples (Table 2).

Table 2

Fatty and organic acids of quince fruits

\begin{tabular}{|c|c|c|c|c|c|c|}
\hline \multirow{2}{*}{ Name of the acid } & \multicolumn{6}{|c|}{ Content in leaves of sorts, $\mathrm{mg} / \mathrm{kg}$ dry plan } \\
\hline & Academichna & Kashchenko N18 & Studentka & Oranzheva & Maria & Darunok onuku \\
\hline Caprinic & & 13.5 & 3.4 & & & \\
\hline Oxalic & 12.2 & 29.6 & 62.8 & 8.2 & 10.4 & 16.5 \\
\hline Malonic & 48.0 & 54.5 & 55.2 & 33.0 & 47.7 & 38.0 \\
\hline Succinic & 31.9 & 21.7 & 40.9 & 60.5 & 73.3 & 45.9 \\
\hline Methoxysuccinic & 6.2 & & & 9.2 & 13.4 & 4.9 \\
\hline Fumaric & 22.4 & 41.0 & 50.1 & 40.3 & 40.4 & 75.3 \\
\hline Benzoic & 6.2 & 5.9 & 42.9 & & & \\
\hline Vanillic & 9.1 & & & & 10.7 & \\
\hline Malic & 3052.5 & 1285.6 & 3235.1 & 7302.5 & 7413.7 & 3105.6 \\
\hline Citric & 105.7 & 183.6 & 159.2 & 82.6 & 233.6 & 105.1 \\
\hline Lauric & 32.2 & 27.1 & 39.8 & 29.5 & 31.6 & 33.3 \\
\hline Myristic & 28.0 & 61.5 & 55.1 & 108.8 & 44.6 & 39.2 \\
\hline Pentadecanoic & 11.3 & 26.3 & 29.5 & 12.0 & 15.2 & 17.1 \\
\hline Palmitic & 1136.0 & 1679.5 & 1379.7 & 1061.5 & 1086.3 & 1130.4 \\
\hline Palmitoleic & 19.6 & 39.8 & 33.8 & 16.8 & 18.8 & 20.3 \\
\hline Heptadecanoic & 25.7 & 46.1 & 40.6 & 25.4 & 25.8 & 31.9 \\
\hline Stearic & 164.4 & 243.1 & 239.2 & 132.8 & 140.0 & 160.3 \\
\hline Oleic & 295.7 & 453.9 & 338.8 & 135.0 & 144.4 & 150.1 \\
\hline 8-Octadecenic & 90.8 & 142.8 & 100.3 & 92.8 & 74.4 & 83.2 \\
\hline Linoleic & 1446.4 & 2252.6 & 1399.6 & 1644.2 & 1779.7 & 1577.8 \\
\hline Linolenic & 429.7 & 458.7 & 391.1 & 389.8 & 478.4 & 432.9 \\
\hline Arachinic & 78.5 & 96.7 & 98.1 & 56.4 & 80.0 & 66.6 \\
\hline 11-Eicosenoic & 17.6 & & & & & \\
\hline 11.14-Eicosadienoic & & 13.6 & & 8.1 & 10.9 & 6.5 \\
\hline Heneicosanoic & & 23.4 & 14.1 & 11.6 & 12.5 & 9.2 \\
\hline Begenic & 49.4 & 88.8 & 112.4 & 37.6 & 88.5 & 36.0 \\
\hline 13-Docosenoic & 61.4 & 95.7 & 78.9 & 35.6 & 118.2 & 21.8 \\
\hline Tetracosanoic & 94.1 & 145.0 & 157.8 & 74.8 & 150.1 & 54.9 \\
\hline 15-Tetracosenoic & 54.7 & 60.3 & 80.3 & 45.1 & 88.6 & 29.6 \\
\hline Pentacosanoic & & & & 9.1 & 18.8 & 9.7 \\
\hline Hexacosanoic & & 138.8 & 272.4 & 77.8 & 147.9 & 75.6 \\
\hline Hexadecadienoic & & 40.3 & & & & \\
\hline
\end{tabular}




\section{Discussion}

As we can see from the Table 1, main organic acids of quince leaves were oxalic and citric acid. Palmitic and linolenic acids were dominated in the fat acids composition. The highest content of citric, palmitic and linoleic acid were identified in the quince leaves of sort "Maria". In addition, the highest amount of all acids was determined in the same sort.

Moreover, a quite high content of succinic acid in the quince leaves was detected: from $208.0 \mathrm{mg} / \mathrm{kg}$ ("Darunok Onuku”) to $557.1 \mathrm{mg} / \mathrm{kg}$ (“Oranzheva”).

It is known, that the succinic acid with citric acid stimulate redox reactions, respiration processes and ATP synthesis, activate organs and tissues physiological functions (stimulate adaptive, compensatory and protective capabilities of the organism), improve physical efficiency. The malonic acid is an antimetabolite of the succinic acid. Interestingly that the maximum ratio of succinic acid and malonic acid is 3:1 in the sort "Orangeva" quince leaves, which shows hepatoprotective properties (the aqueous extract).

The results in Table 2 showed that the content of organic acid is higher in leaves than in fruits, except the malic acid which dominates among organic acids in quince fruits. Similar data were received by Portuguese explorers on local sorts of quince. Even though Portuguese quince sorts leaves had insignificant content of oxalic acid, other dibasic acids were not identified in them [27]. According with the Table 2, in quince fruits as well as in quince leaves, palmitic acid was the main fatty acid. Moreover, linoleic acid was dominated among of unsaturated fatty acids.

\section{Conclusions}

1. The presence of 36 fatty acids and 32 organic acids in leaves and fruits of the quince were identified and their content was determined by gas chromatography-mass spectrometry method.

2. Main acids were oxalic, citric, palmitic and linolenic acids in quince leaves and malic, palmitic and linoleic acids in quince fruits.

3. The highest content of all acids were in the quince leaves of sort "Maria".

\section{References}

[1] Brown, V. A., Lozano, J. E., Genovese, D. B. (2013). Pectin extraction from quince (Cydonia oblonga) pomace applying alternative methods: Effect of process variables and preliminary optimization. Food Science and Technology International, 20 (2), 83-98. doi: 10.1177/1082013212469616

[2] Carvalho, M., Silva, B. M., Silva, R., Valentao, P., Andrade, P. B., Bastos, M. L. (2010). First Report on Cydonia oblonga Miller Anticancer Potential: Differential Antiproliferative Effect against Human Kidney and Colon Cancer Cells. Journal of Agricultural and Food Chemistry, 58 (6), 3366-3370. doi: 10.1021/jf903836k

[3] Daneshvand, B., Ara, K. M., Raofie, F. (2012). Comparison of supercritical fluid extraction and ultrasound-assisted extraction of fatty acids from quince (Cydonia oblonga Miller) seed using response surface methodology and central composite design. Journal of Chromatography A, 1252, 1-7. doi: 10.1016/ j.chroma.2012.06.063

[4] Fattouch, S., Caboni, P., Coroneo, V., Tuberoso, C. I. G., Angioni, A., Dessi, S. et. al. (2007). Antimicrobial Activity of Tunisian Quince ( Cydonia oblonga Miller) Pulp and Peel Polyphenolic Extracts. Journal of Agricultural and Food Chemistry, 55 (3), 963-969. doi: 10.1021/jf062614e

[5] Fiorentino, A., D’Abrosca, B., Pacifico, S., Mastellone, C., Piscopo, V., Caputo, R., Monaco, P. (2008). Isolation and Structure Elucidation of Antioxidant Polyphenols from Quince (Cydonia vulgaris) Peels. Journal of Agricultural and Food Chemistry, 56 (8), 2660-2667. doi: 10.1021/jf800059r

[6] Ganopoulos, I., Merkouropoulos, G., Pantazis, S., Tsipouridis, C., Tsaftaris, A. (2011). Assessing molecular and morpho-agronomical diversity and identification of ISSR markers associated with fruit traits in quince (Cydonia oblonga). Genetics and Molecular Research, 10 (4), 2729-2746. doi: 10.4238/2011.november.4.7

[7] Gheisari, H. R., Abhari, K. H. (2014). Drying method effects on the antioxidant activity of quince (Cydonia oblonga Miller) tea. Acta Scientiarum Polonorum Technologia Alimentaria, 13 (2), 129-134. doi: 10.17306/j.afs.2014.2.2

[8] Kawahara, T., Iizuka, T. (2011). Erratum to: Inhibitory effect of hot-water extract of quince (Cydonia oblonga) on immunoglobulin E-dependent late-phase immune reactions of mast cells. Cytotechnology, 63 (5), 541-542. doi: 10.1007/s10616-011-9370-9 
[9] Magalhaes, A. S., Silva, B. M., Pereira, J. A., Andrade, P. B., Valentao, P., Carvalho, M. (2009). Protective effect of quince (Cydonia oblonga Miller) fruit against oxidative hemolysis of human erythrocytes. Food and Chemical Toxicology, 47 (6), 1372-1377. doi: 10.1016/j.fct.2009.03.017

[10] Minaiyan, M., Ghannadi, A., Etemad, M., Mahzouni, P. (2012). A study of the effects of Cydonia oblonga Miller (Quince) on TNBS-induced ulcerative colitis in rats. Research in Pharmaceutical Sciences, 7 (2), 103-110.

[11] Morelli, M., Giampetruzzi, A., Laghezza, L., Catalano, L., Savino, V. N., Saldarelli, P. (2016). Identification and characterization of an isolate of apple green crinkle associated virus involved in a severe disease of quince (Cydonia oblonga, Mill.). Archives of Virology. doi: 10.1007/s00705-016-3074-6

[12] Oliveira, A. P., Pereira, J. A., Andrade, P. B., Valentao, P., Seabra, R. M., Silva, B. M. (2007). Phenolic Profile of Cydonia oblonga Miller Leaves. Journal of Agricultural and Food Chemistry, 55 (19), 7926-7930. doi: 10.1021/jf0711237

[13] Osman, A. G. M., Koutb, M., Sayed, A. E.-D. H. (2010). Use of hematological parameters to assess the efficiency of quince (Cydonia oblonga Miller) leaf extract in alleviation of the effect of ultraviolet $-\mathrm{A}$ radiation on African catfish Clarias gariepinus (Burchell, 1822). Journal of Photochemistry and Photobiology B: Biology, 99 (1), 1-8. doi: 10.1016/j.jphotobiol.2010.01.002

[14] Shinomiya, F., Hamauzu, Y., Kawahara, T. (2009). Anti-Allergic Effect of a Hot-Water Extract of Quince (Cydonia oblonga). Bioscience, Biotechnology, and Biochemistry, 73 (8), 1773-1778. doi: 10.1271/ bbb. 90130

[15] Wojdylo, A., Oszmianski, J., Bielicki, P. (2013). Polyphenolic Composition, Antioxidant Activity, and Polyphenol Oxidase (PPO) Activity of Quince (Cydonia oblonga Miller) Varieties. Journal of Agricultural and Food Chemistry, 61 (11), 2762-2772. doi: 10.1021/jf304969b

[16] Klymenko, S. (2011). Quince: bioecology, morphology, reproduction, varieties. Kyiv: Logos, 243.

[17] Dzhan, T., Konovalova, O., Klymenko, S. (2010). Study of accumulation of bioactive compounds in the leaves of quince regular (Cydonia oblonga L.). Pharmaceutical journal, 6, 97-100.

[18] Dzhan, T. (2011). Determination of triterpene compounds in fruits. seeds. leaves and flowers of quince (Cydonia oblonga L.). Pharmacology and medical toxicology, 5, 96-97.

[19] Dzhan, T., Konovalova, O., Klymenko, S. (2011). Determination of procyanidins content in the leaves and fruits of Japan quince and quince different species. Phytotherapy, 1, 72-74.

[20] Dzhan, T., Konovalova, O., Klymenko, S. (2010). The study of amino acids content in fruits, leaves and flowers of quince (Cydonia oblonga L.). Phytotherapy, 2, 80-81.

[21] Dzhan, T., Konovalova, O., Klymenko, S. (2011). The study of polysaccharide content in the fruits of quinces Cydonia oblonga L. Modern trends in medicine. Veterinary science and pharmacology development. Odesa: In Press, 97-98.

[22] Dzhan, T., Konovalova, O., Klymenko, S. (2012). Component composition of essential oil of fruits and leaves of quince. Pharmacy and Public Health, 166-170.

[23] Dzhan, T., Konovalova, O., Klymenko, S., Kutsenko, T. (2011). Study of antiulcer action of quince fruit Cydonia oblonga L. and Japan quince Chaenomeles Lindl. Scientific Papers of researchers of the National Medical Academy of Postgraduate Education, 20, 474-478.

[24] Dzhan, T., Konovalova, O., Klymenko, S., Yadlovsky, O. (2012). The study of hypoglycemic activity of quince (Cydonia oblonga L.) and Japan quince (Chaenomeles L.) leaves. Pharmacology and medical toxicology, 6, 52-57.

[25] Dzhan, T., Konovalova, O., Klymenko, S., Yadlovsky, O. (2012). Research of quince Cydonia oblonga Mill. fruit effect on the blood. Development. Research and marketing of new pharmaceuticals, 68, 308-310.

[26] Dzhan, T., Kuznietsova, O., Klymenko, S. (2013). Research of antiulcer activity of quince leaves extracts. Scientific and technological progress and optimization of technological processes of creation of drugs. Ternopil: Ternopil State Medical University, 368-369.

[27] Oliveira, A. P., Pereira, J. A., Andrade, P. B., Valentao, P., Seabra, R. M., Silva, B. M. (2008). Organic acids composition of Cydonia oblonga Miller leaf. Food Chemistry, 111 (2), 393-399. doi: 10.1016/ j.foodchem.2008.04.004 